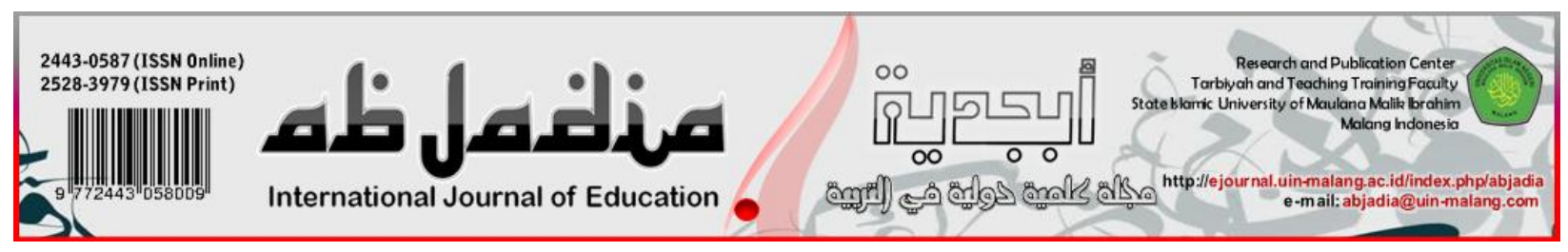

\title{
INTEGRATIVE MATHEMATICS LEARNING: STUDY OF HADITS ON NUMBER
}

\author{
Novita Erni Hendrawati', Suci Wulandari'2, Moh. Miftakhul Ulum³, \\ Muhammad Hasan Asnawi', Imam Rofiki', Abdussakir \\ 1,2,3,4,5,6 Universitas Islam Negeri Maulana Malik Ibrahim Malang, Indonesia
}

Article History:

Received : 22-01-2020

Revised : 22-03-2020

Accepted : 09-06-2020

Published : 30-06-2020

\section{Keywords:}

Hadith; Integer Numbers, Number

Operations, Integrative Mathematics

Learning

$\overline{\text { Correspondence Address: }}$ novitaerni25@gmail.com wsuci230223@gmail.com ululum24@gmail.com

hasan.asnawi6127@gmail.com

imam.rofiki@uin-malang.ac.id

sakir@mat.uin-malang.ac.id

\begin{abstract}
Integrative mathematics learning is needed in the study of science and religion, especially in the madrassa and the Islamic University, to improve morality for all students in Indonesia. This study aims to examine the hadith regarding integers and integer operations in integrative mathematics learning. Mathematical learning is expected to increase students' religious knowledge and mathematical knowledge. The method used in this research is literature study. In the hadith, some integers are $1,2,3,4,5,6,7,8,9,10$ and integer operations, namely addition, subtraction, multiplication, and division. The hadiths related to numbers and number operations are HR. Bukhari 40; 71; 15; 33; 1334; 1761; 1109, HR. Muslim 19; 1984; 1513; 1991, HR. Darmini 3174, HR. Ibnu Khuzaimah 301, and HR. Tirmidhi 565.
\end{abstract}

\section{(C) Introduction}

Islamic values are values that are sourced directly from the Qur'an and the Hadith have an important meaning in the value of education, especially for Muslims (Asyhari, 2017; Baba, 2018; Nasution, 2014). This is in accordance with the mandate of the Ministry of Religion that integration is needed for learning science and religion, especially in the madrassa and Islamic University throughout Indonesia in the hope of increasing good morals for all students (Direktorat Jendral Pendidikan Islam, 2011). So based on the explanation, integration can be an intermediary for students to be more devoted to Allah SWT.

The several integration models formulated by Abdussakir \& Rosimanidar (2017) are as follows: 1) Developing mathematics from the Qur'an (mathematics from the Qur'an); 2) Using mathematics to carry out the Qur'an; 3) Using mathematics to uncover mathematical wonders of the Qur'an (mathematics to the Qur'an); and 4) Teach mathematics with the values of the Qur'an (Mathematics with the Qur'an). 
Previous research on the integration of mathematics with the Qur'an and the hadith included a model of integration of mathematics with Islamic values and local cultural wisdom in the learning of mathematics by Mutijah (2018), learning mathematics in the perspective of the Qur'an by Nu'man (2016), the development of an integrated mathematical model of Islamic values through the Realistic Mathematics Education (RME) approach (Yuniati \& Sari, 2018), fractional numbers in hadith (Hapiz, Affifudin, Annisa, Rofiki, \& Abdussakir, 2019), the integration of values the value of islam with the material set to the verses of the Qur'an by (Nihayati, 2017) and learning integrative mathematics on the set material in the al-Qur'an study by Wulandari, Hendrawati, Adawia, Dinantika, Rofiki, \& Abdussakir (2019).

Numbers are one of the basic knowledge in mathematics. Numbers are a mathematical concept used for solving and measuring (Altman, 2019; Davarpanah \& Mirshekari, 2019; Dudley \& Dudley, 2012; Tristianto, Linawati, \& Susanto, 2018). Symbols or symbols used to represent a number are called numbers or symbols. So that number is an abstract idea that will provide information about the number of a collection of objects (Buijsman, 2019; Suwarto, 2018). Therefore, the need for mathematical integration in integer material and integer operations. This is because integers and integer operations are basic knowledge in mathematics that will be used as a basis for other mathematical concepts.

The purpose of writing this article is to examine integers and integer operations in the hadith. The results of this study can be used as reference in the learning process of integer materials and integer operations integrated in the hadith.

\section{[Q] Method}

The method used in this research is literature study. The literature in this study is to select the books of hadith relating to numbers and number operations. Next, we analyze and describe the hadiths.

\section{Result}

The results of this study are divided into two parts, namely:

\section{Forms of Positive Round Numbers (1-10) in the Hadith}

Number is a mathematical concept used for solving and measuring. Symbols or symbols used to represent a number are called numbers or symbols. Number is an abstract idea that will give information about the number of a collection of objects.

\section{Integer Number 1}

Narrated by HR. Bukhari number 40 that: 


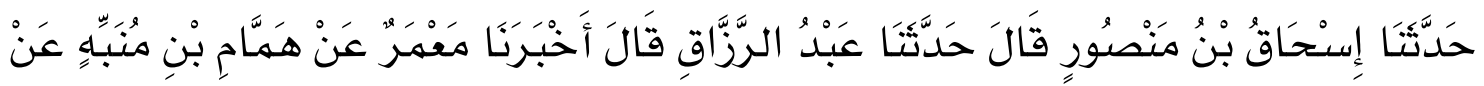

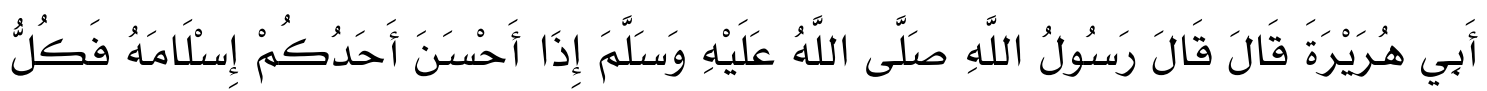

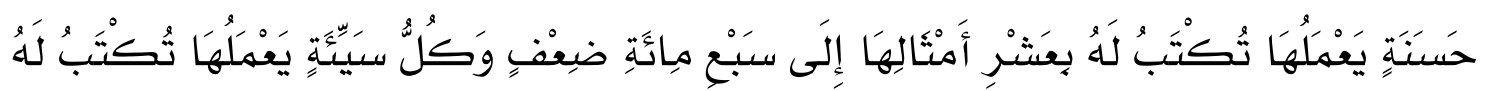

Meaning: Having told us Ishaq bin Manshur said he had told us Abdurrazzaq said he had preached to us Ma'mar from Hamam bin Munabbih from Abu Hurairah said: Rasulullah sallallaahu 'alaihi wa sallam said: "If one of your repairs his Islam, then from each goodness will be written for him ten (goodness) which are similar to seven hundred levels, and for every bad thing done it will be written for just one ugliness similar to him."

\section{Integer Number 2}

Narrated by HR. Bukhari number 71 that:

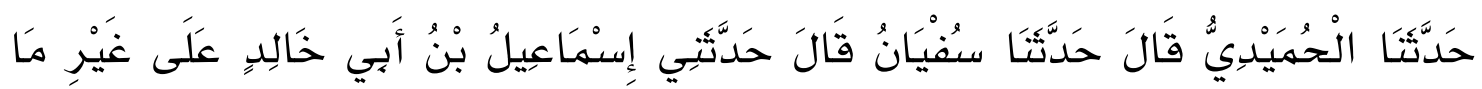

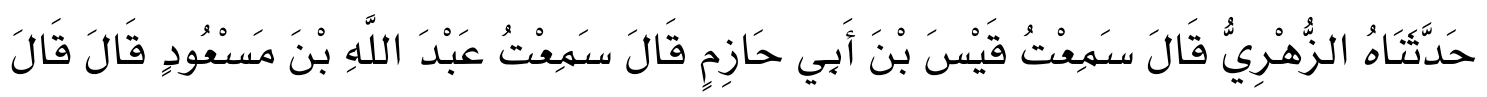

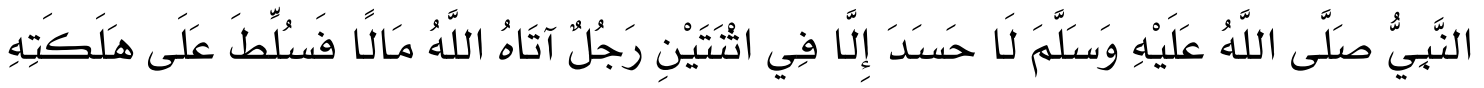

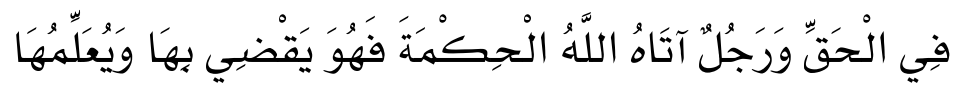

Meaning: Has told us Al Humaidi said: has told us Sufyan said: told me Isma'il bin Abu Khalid - with lafazh another hadith than what he told us from $\mathrm{Az}$ Zuhri - said: I heard Qais bin Abu Hazim said: I heard Abdullah bin Mas'ud said: The Prophet sallallaahu 'alaihi wa sallam said: "You cannot envy except for two things: (to) a person whom Allah gave wealth then he used the treasure in the way of truth and someone whom Allah gave wisdom then he practices and teaches it to others."

\section{Integer Number 3}

Narrated by HR. Bukhari number. 15 that:

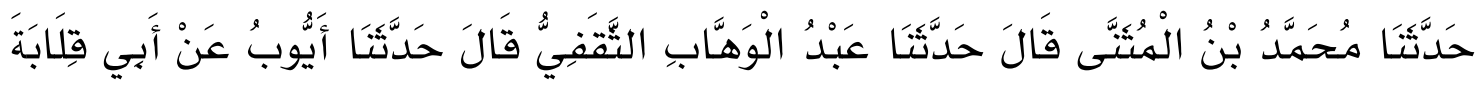

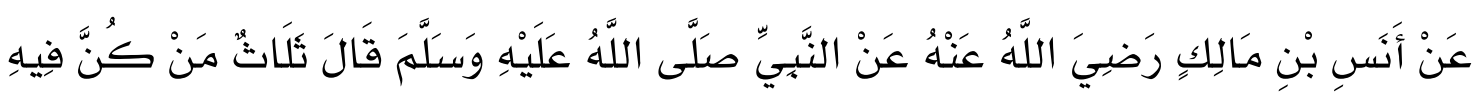

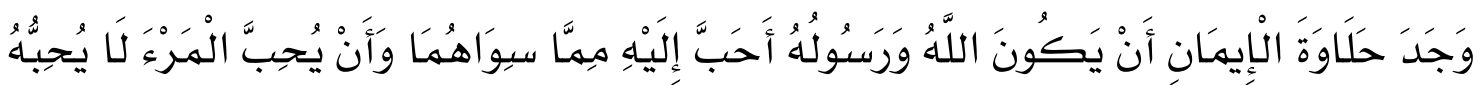

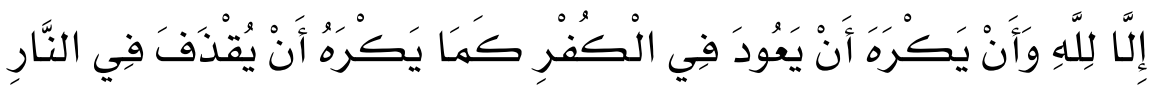


Meaning: Having told us Muhammad bin Al Mutsanna said: had told us Abdul Wahhab Ats Tsaqafi said: had told us Ayyub from Abu Qilabah from Anas bin Malik from the Prophet sallallaahu 'alaihi wa sallam, he said: "Three cases when there is in someone, he will get the sweetness of faith: He made Allah and His Messenger more beloved than the other two. If he loves someone, he does not love him except because of Allah. And he hates returning to kufr as he hates when thrown into hell."

\section{Integer Number 4}

Narrated by HR. Bukhari number. 33 that:

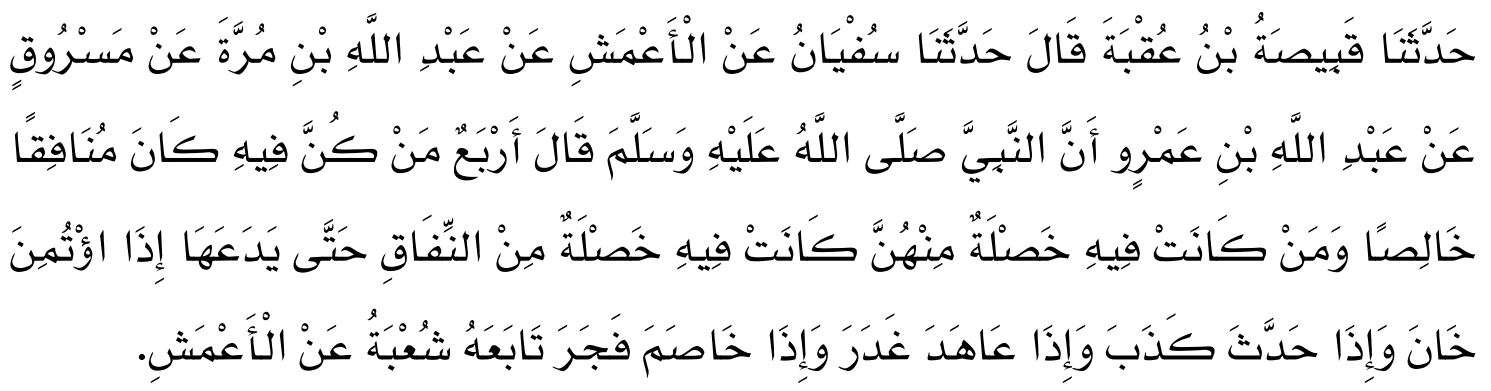

Meaning: have told us Qabishah bin 'Uqbah said: have told us Sufyan from Al A'masy from Abdullah bin Murrah from Masruq from Abdullah bin' Amru that the Prophet sallallaahu 'alaihi wa sallam said: "Four things if there is someone he is a genuine munafiq, and whoever is in him is one of the four things, then in him there is a nifaq character until he leaves it, that is, if given the mandate he betrays, if he speaks a lie, if he promises to deny and if he fights cheating".

\section{Integer Number 5}

Narrated by HR. Muslim number. 19 that:

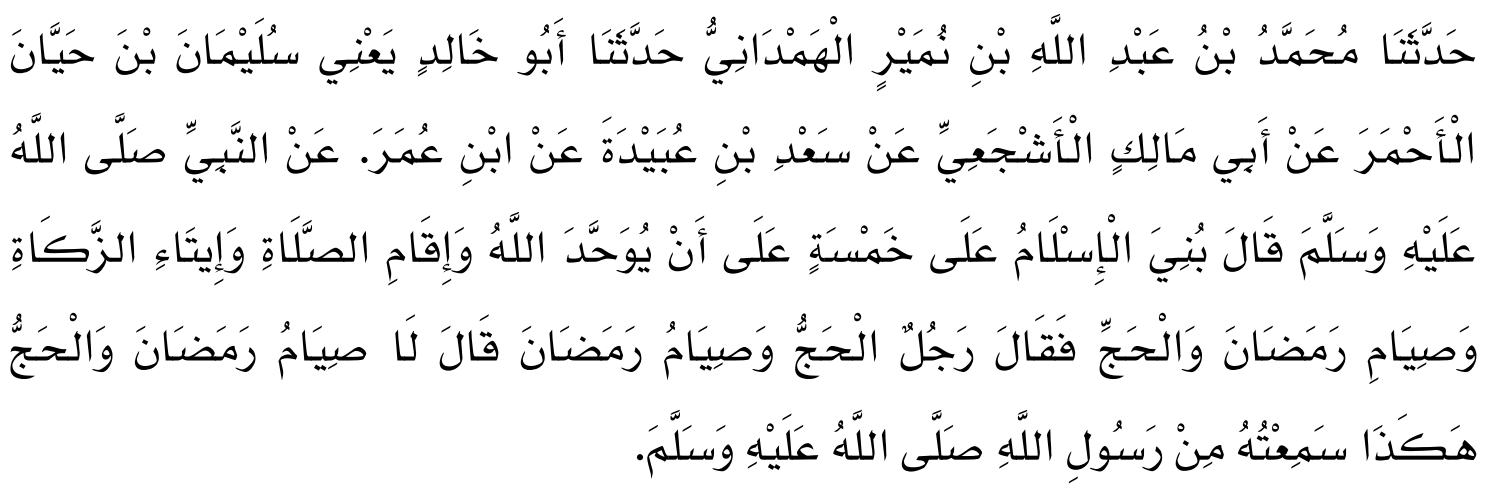

Meaning: Having told us Muhammad bin Abdullah bin Numair al-Hamdani told us Abu Khalid - i.e. Sulaiman bin Hayyan al-Ahmar- from Abu Malik alAsyja'i from Sa'ad bin Ubaidah from Ibn Umar from the Prophet sallallaahu'alaihi wa sallam, he said: "Islam is built on five foundations, namely in order to bring God, establish prayer, pay zakat, fast Ramadan, and pilgrimage." A man asked: "What is the pilgrimage and (then) Ramadan fasting." Ibn Umar 
replied: "No, fasting Ramadan and (then) the pilgrimage. Thus I heard it from the Prophet sallallaahu 'alaihi wa sallam."

\section{Integer Number 6}

Narrated by HR. Muslim number 1984 that:

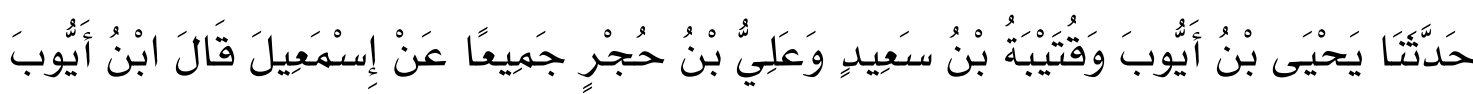

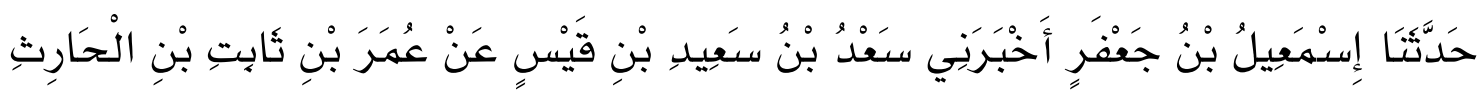

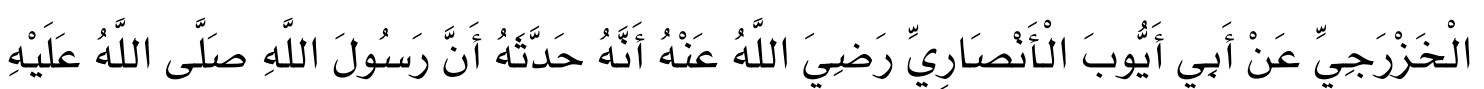

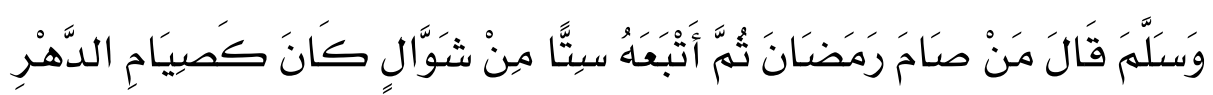

Meaning: Having told us Yahya bin Ayyub and Qutaibah bin Sa'id and Ali bin Hujr all from Isma'il - Ibn Ayyub said - Has told us Isma'il bin Ja'far had preached to me Sa'd bin Sa'id bin Qais from Umar bin Thabit bin Harith Al Khazraji from Abu Ayyub Al Anshari radliallahu 'anhu, that he had told him that the Messenger of Allah sallallaahu' alaihi wa sallam said: "Who fasts Ramadan then accompanies him by fasting six days in Shawwal, then who told thus it is as if fasting all the time".

\section{Integer Number 7}

Narrated by HR. Bukhari number 1334 that:

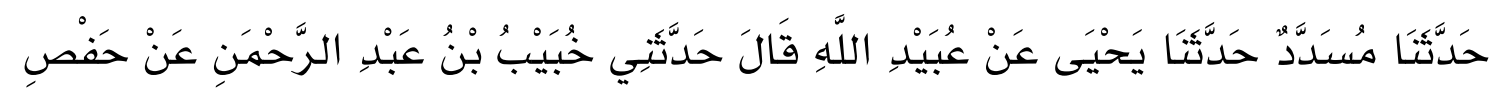

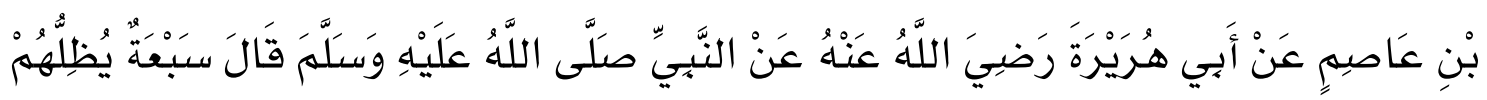

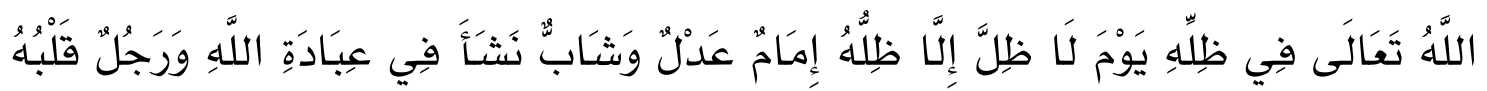

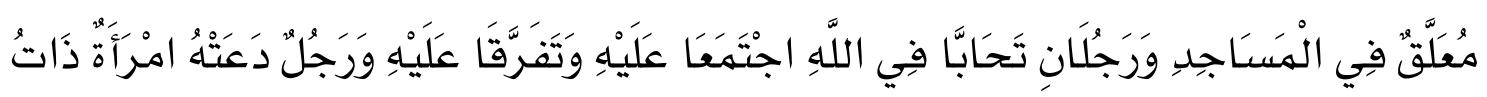

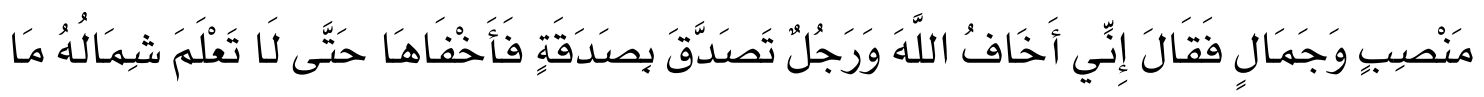

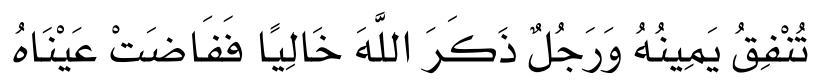

Meaning: Having told us Musaddad had told us Yahya from 'Ubaidullah said: had told me Khubaib bin' Abdurrahman from Hafsh bin 'Ashim from Abu Hurairah radliyallahu' anhu from the Prophet sallallaahu 'alaihi wa sallam said: "There are seven (groups) a believer) who will receive shelter (protection) from Allah under His shade (on the day of qiyamat) which when there is no shade except His shade. Namely: A just leader, a young man who busied himself with worship to his Rab, a man whose heart is attached to a mosque, two men who love each other for Allah, both meet because of Allah and separate because of Allah, a man who was invited to commit immorality by a beautiful, rich woman and then he said: "I fear Allah", a 
person who gives charity by hiding it so that his left hand does not know what is said by his right hand, and a man who is remembers Allah by alienating himself alone until his eyes wet from crying."

\section{Integer Number 8}

Narrated by HR. Muslim number. 1513 that:

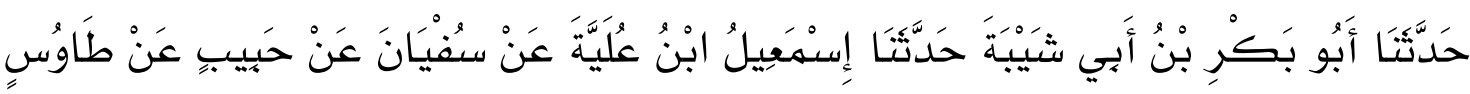

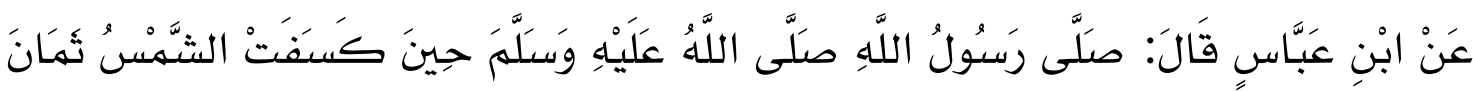

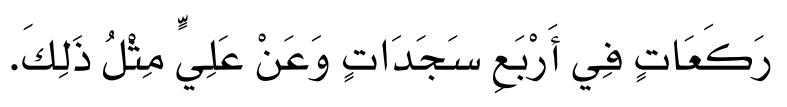

Meaning: has told us Abu Bakr ibn Abu Syaibah has told us Isma'il bin Ulayyah from Sufyan from Habib from Thawus from Ibn Abbas he said: "When there was a solar eclipse, the Prophet sallallaahu 'alaihi wa sallam prayer (eclipse) with eight times bowing 'and four times prostration (in two rak'ats). And from Ali ibn Abu Talib it was also reported like that."

\section{Integer Number 9}

Narrated by HR. Muslim number 1991 that:

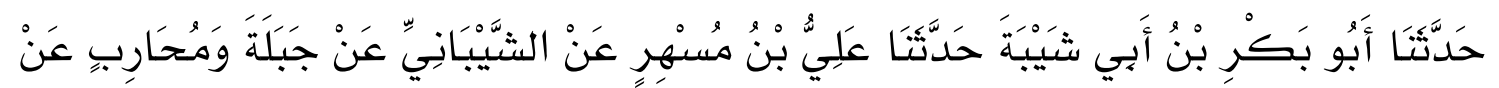

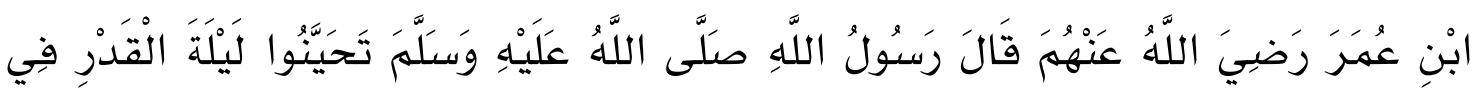

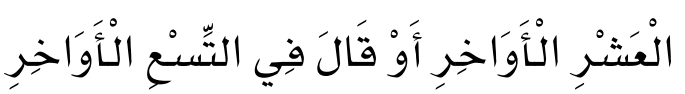

Meaning: Having told us Abu Bakr bin Abu Syaibah had told us Ali bin Mushir from Asy Syaibani from Jabalah and Muharib from Ibn Umar radliallahu 'anhuma, he said: Rasulullah sallallaahu' alaihi wa sallam said: "Look for Lailatul Qadr on ten days last-or he said - in the last nine days (of the month of Ramadan)."

\section{Integer Number 10}

Narrated by HR. Bukhari number. 1761 that:

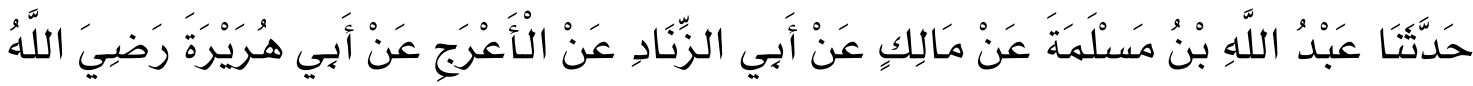

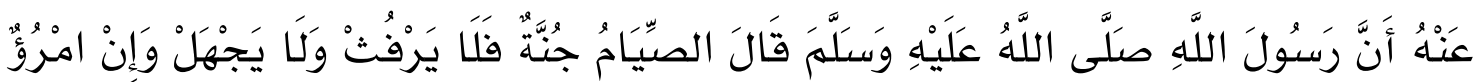

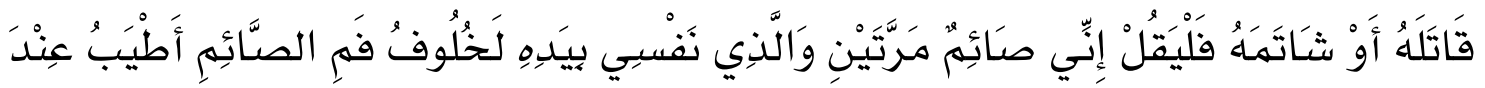

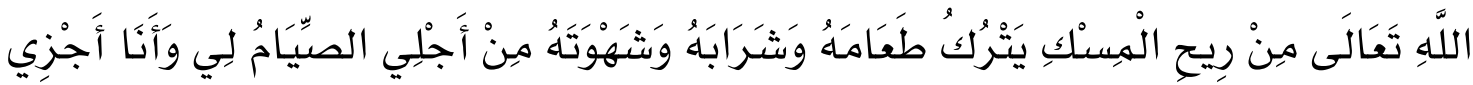

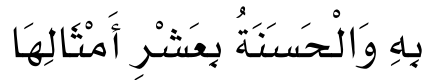


Meaning: Having told us' Abdullah bin Maslamah from Malik from Abu Az Zanad from Al A'raj from Abu Hurairah radliyallahu'anhu: That the Prophet sallallaahu' alaihi wa sallam said: "Shaum is a fortress, (those who carry it out) do not do dirty (rafats) and do not also do stupid.If anyone who invites him to fight or insult him then say: 'I am shaum' he repeated his words twice. And for the sake of the Essence that my soul is in his hand, really bad breath of people who are shaum more fragrant with Allah the Exalted from the fragrance of the oil of misik, because he left his food, drink and lust because of me. Shaum is for me and I myself will repay and every one goodness is rewarded with ten similar goodness."

\section{Number Operations in Hadith}

The existence of numbers and relationships is incomplete, if you cannot take action on a particular partner. Performing an action on a pair of numbers can be called "number operation."

\section{Addition Operation}

Narrated HR. Bukhari number 1109 concerning the sunnah prayers performed by Rasullah, that:

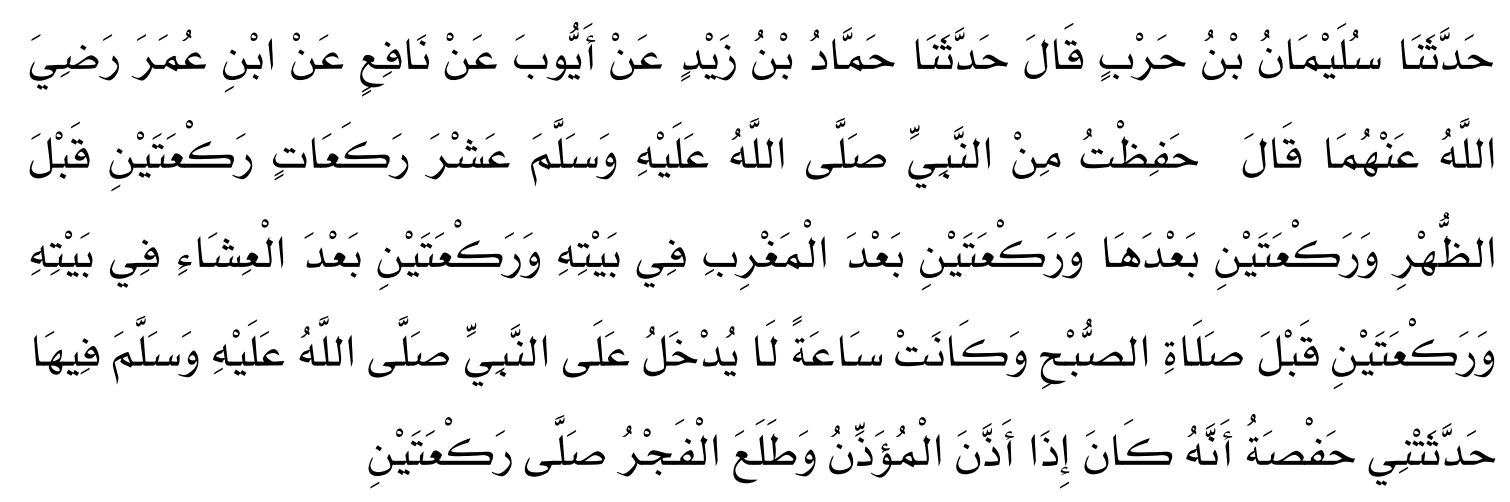

Meaning: Having told us Sulaiman bin Harb said: had told us Hammad bin Zaid from Ayyub from Nafi 'from' Abdullah bin 'Umar radliyallahu' anhu said: "I memorize something from the Prophet sallallaahu 'alaihi wa sallam in the form of the ten-raka sunnah prayer 'at ie: two rak'ahs before Dhuhr prayer, two rak'ahs afterward, two ra' ahs after Maghrib prayer at his house, two rak'ahs after' Isha 'prayer at his house and two rak'ahs before the morning prayer, and at the time of this prayer there is no free time for the Prophet sallallaahu 'alaihi wa sallam. Had told me Hafshah that if the Mu'adzin had echoed the call to prayer and the dawn had risen, he prayed the two rak'ahs.

\section{Multiplication Operation}

Narrated HR. Darmini number. 3174 concerning the virtue of reading the Qur'an that: 


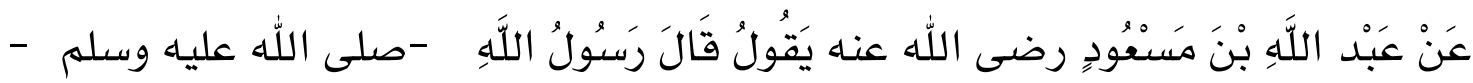

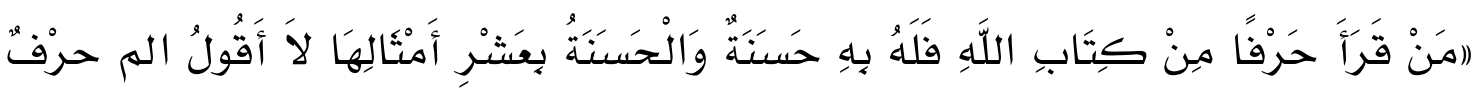

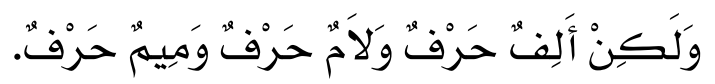

Meaning: Having told us Abu Amir Qabishah had preached to us Sufyan from 'Atha bin As Sa ib from Abu Al Ahwash from Abdullah he said: "Learn the Qur'an, because you will be rewarded by reading it, each letter with ten goodness. I do not say alif lam mim is one letter, but alif one letter, lam one letter, and one letter mim, each letter is rewarded with ten virtues. "

\section{Subtraction Operation}

The hadith narrated about the story of isra 'mi'raj in general has been told by Allah SWT in his word surah Al-Isra' verse 1 namely:

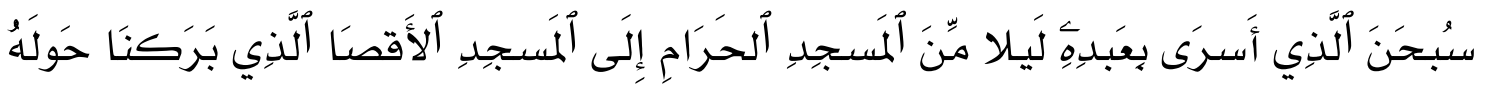

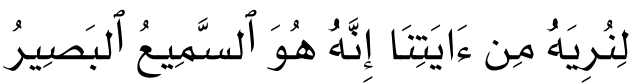

Meaning: Glory to Allah, who has run His servant one night from Al Masjidil Haram to Al Masjidil Aqsa which We have blessed around him so that We show him some of our signs (greatness). Verily, He is All-Hearing, AllKnowing (QS. Al-Isra ayat 1) the details and sequence of events are found in many authentic hadiths with various narrations. One of them is the hadith which is stated by the authentic hadith of Khuzaimah number 301 regarding the relief of Allah for the obligation to pray for the people of Prophet Muhammad SAW, namely:

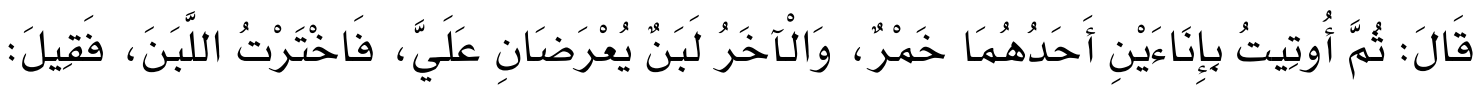

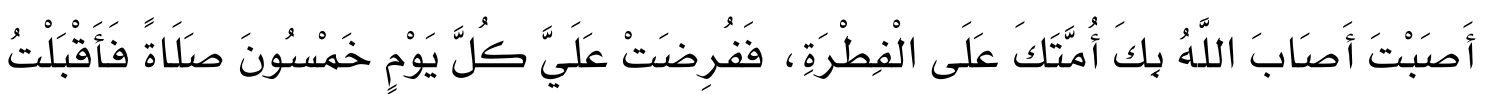

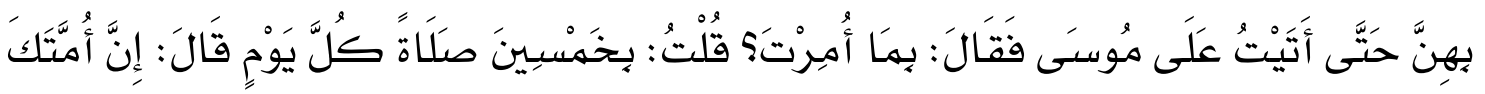

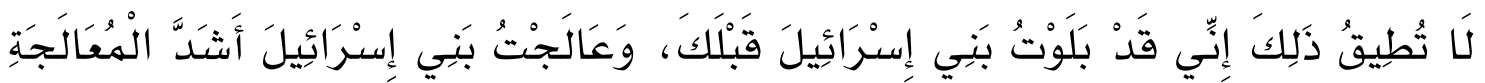

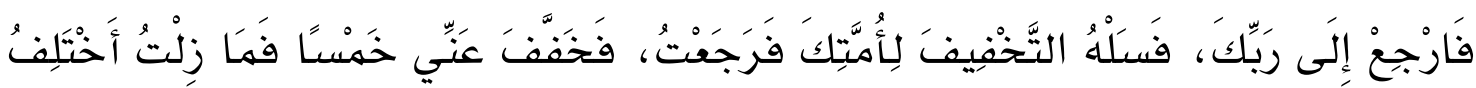

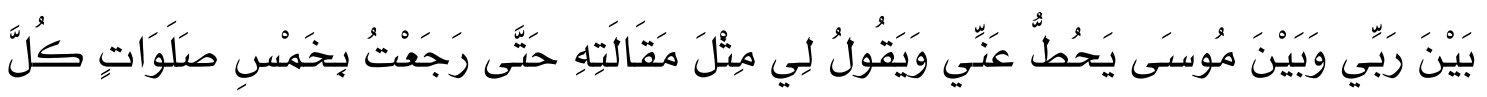

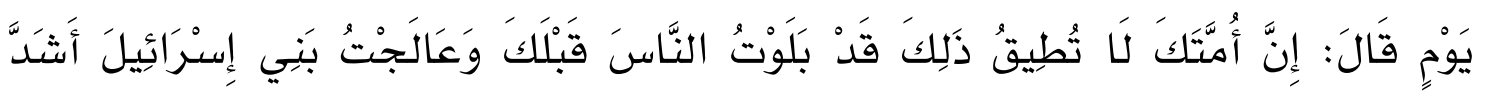

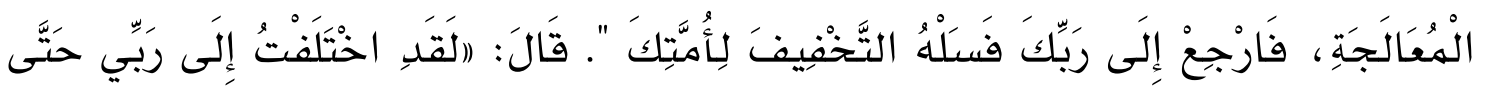




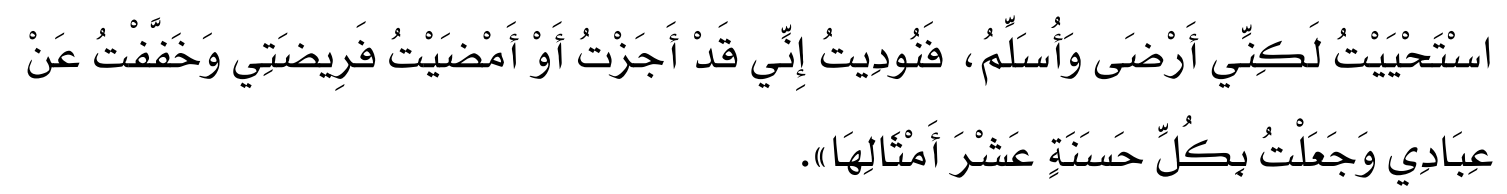

Meaning: It says, "You are right, God has chosen your people to be fitrah." Then fifty-day prayers are required to be done every day, then I accept them until I meet the prophet Musa (as). Then he said, "What has been ordered to you?" (45-alif) I answered, "Praying fifty cycles in one day." Prophet Musa replied, "Surely your people will not be strong. Indeed, I have tried the Children of Israel before you, and I have taken care of the children of Israel - to carry out - often but cannot. Then return to your Lord and ask for relief from your people, then I return, then Allah SWT gives me five rakats of lightening. I still went repeatedly between my Lord and Prophet Moses, who stopped me. The prophet Musa said like the last words, until I brought back five prayers every day. The Prophet Musa said, "Surely your people will not be able to. Truly I have tested the people before you and I have taken care of the children of Israel to carry it out seriously but cannot. Return to your Lord and ask for relief for your people "The Prophet sallallaahu 'alaihi wa sallam said," Really I have gone repeatedly to my Lord, until I was ashamed, but I was pleased and accepted. Then I am called, verily I have been permitted or I have done my duty and have been lightened for my servants and made for every good, ten times the reward."

\section{Division Operation}

Narrated HR. Tirmidhi number.565 regarding the distribution of zakat for cattle that must be issued by His servant that:

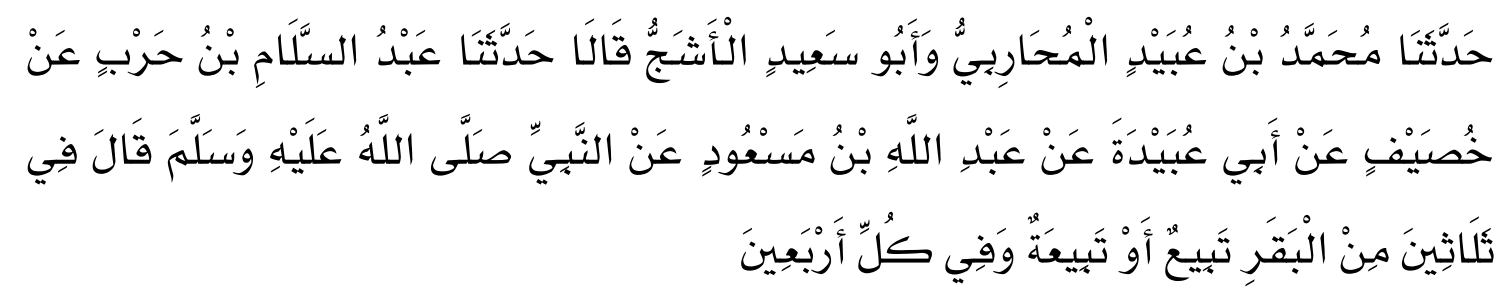

Meaning: Having told us Muhammad bin 'Ubaid Al Muharibi and Abu Sa'id Al Asyajj both said, had told us' Abdus Salam bin Harb from Khushaif from Abu' Ubaidah from Abdullah bin Mas'ud from the Prophet Salallahu wa alaihi wa salam He said: In every thirty cows, one zakat is Tabi 'or Tabi'ah (bulls or females that have entered the second year) and in each forty cows, one zakat is Musinnah (which has entered the third year).

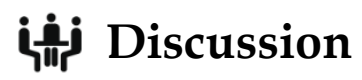

Based on the results of the hadith study that has been explained, the discussion 
of the results of the exposure is as follows:

Forms of Positive Round Numbers (1-10) in the Hadith

Integer Number 1 on the Hadith of Bukhari Number 40

Based on the authentic hadith of the history of Bukhari number 40 it can be concluded that every ugliness done by humans will be written by angels an ugliness similar to it, while those who do good deeds will be written ten (goodness).

\section{Integer Number 2 on the Hadith of Bukhari Number 71}

Based on the authentic hadith of Bukhari number 71, it can be concluded that we as humans are forbidden to deal with anything except 2 things, namely:

1. A servant to whom Allah gave wealth then he used the treasure in the way of truth

2. Someone who Allah gives guidance in the form of wisdom then he practices and teaches it to others

\section{Integer Number 3 on the Hadith of Bukhari Number 15}

Based on the authentic history of Bukhari hadith number 15, it can be concluded that there are 3 cases that if there is a servant of Allah, he will get the sweetness of faith, namely:

1. He made Allah and Rasul more beloved than both

2. If he loves someone, he does not love him except because of God

3. Allah hates kufr

\section{Integer Number 4 on the Hadith of Bukhari Number 33}

Based on the authentic hadith of Bukhari number 33, it can be concluded that there are 4 things that characterize a hypocrite, namely:

1. If given the message he betrayed

2. If when talking lies

3. If you promise to renege

4. If hostile cheat.

\section{Integer Number 5 on the Hadith of Muslim Number 19}

Based on the authentic hadith of Muslim history number 19, it can be concluded that Islam is built on 5 foundations, namely:

1. Monotheism to Allah SWT (reading shahada)

2. Establish prayer

3. Paying alms

4. Fasting in the month of Ramadan 
5. Hajj

Integer Number 6 on the Hadith of Muslim Number 1984

Based on the authentic hadith of Muslim history no 1984, it can be concluded that a servant of Allah who fasted in the month of Ramadan and was accompanied by a 6 day fast in Syawwal then seemed to fast all the time.

\section{Integer Number 7 on the Hadith of Bukhari Number 1334}

Based on the authentic hadith of Bukhari's history no. 1334, it can be concluded that there are 7 groups that get protection from Allah SWT, namely:

1.Fair leader

1. A young man who engages himself in worship with His Rabb

2. A man whose heart is attached to a mosque

3. Two people who love each other because of God

4. A man who is invited to commit immorality by a beautiful, rich woman and then he says: "I fear Allah"

5. A person who gives charity by hiding it until his left hand does not know what is said by his right hand

6. A man who dhikr to Allah by isolating himself alone until his eyes are wet from crying

\section{Integer Number 8 on the Hadith of Muslim Number 1513}

Based on the hadith of Muslim history number 1513 it can be concluded that the eclipse prayer is performed in two rak'ahs with eight bowing rows and four prostrations.

\section{Integer Number 9 on the Hadith of Muslim Number 1991}

Based on the authentic hadith of Muslim history number 1991 can be concluded that the night of Laylat al-Qadr is between the tenth day and the last nine days of the month of Ramadan.

\section{Integer Number 10 on the Hadith of Bukhari Number 1761}

Based on the authentic hadith Bukhari number 1761 it can be concluded that whoever fasts because of Allah and keeps himself from illicit acts, one good deed will be rewarded with ten similar goodies.

\section{Number Operations in Hadith}

\section{Addition Operation on the Hadith Muslim Number 939}

Based on the authentic hadith of Muslim history number 939 it can be concluded that there are ten raka'at sunnah prayers that are recommended. The relationship between the hadith and the integer addition operation is $2+2+2+2+2=10$. 


\section{Multiplication Operation on the Hadith Damini Number 3174}

Based on authentic hadith narrated by authentic history Darmini number. 3174 then the relationship between the hadith and integer multiplication operations that is three letters alif, lam, meme that is read will get thirty goodness or 3 letters $\times 10$ goodness $=30$ goodness.

\section{Subtraction Operation on the Hadith Saheeh Ibn Khuzaimah Number 301}

Based on the hadith narrated by Saheeh Ibn Khuzaimah number.301, the relationship between the hadith and the operation of reducing integers is that initially Allah SWT obliged the people of the Prophet Muhammad about the obligation to pray as much as 50 times. However, the Prophet Muhammad negotiated with Allah SWT so that he was obliged to perform the obligatory prayers 5 times. So, the number of obligatory prayers that must be performed by the people of the Prophet Muhammad is 5 times the obligatory prayers every day.

\section{Devision Operation on the hadiths Tirmidhi number 565}

Based on the explanation of the authentic hadith of history Tirmidhi number. 565 with the concept of positive integers in mathematics, the Prophet Muhammad SAW regarding payment of cow livestock is presented in Table. 1.

Tabel.1 Levels of compulsory zakat on cows

\begin{tabular}{cll}
\hline No & Nishob (number of cows) & Obligatory levels of zakat \\
\hline 1 & $30-39$ tails & 1 tabi '(1 year old male bull) or tabi'ah (2 year old female cow) \\
\hline 2 & $40-59$ tails & 1 musinnah (2 year old female cow) \\
\hline 3 & $60-69$ tails & 2 tabi' \\
\hline 4 & $70-79$ tails & 1 musinnah and 1 tabi' \\
\hline 5 & $80-89$ tails & 2 musinnah \\
\hline 6 & $90-99$ tails & 3 tabi' \\
\hline 7 & $100-109$ tails & 1 musinnah and 2 tabi' \\
\hline 8 & $110-119$ tails & 2 musinnah and 1 tabi' \\
\hline 9 & 120 tails on the up & Every $30: 1$ tabi 'or tabi'ah, every 40 cows: 1 musinnah \\
\hline
\end{tabular}

Based on the explanation in Table 1, it is known that if a slave has 130 cows, he is obliged to pay the tabi'and 1 destruction or if it is related to the division using integer reduction operations, it is obtained 130-30-30-30-40 $=0$.

\section{眘 Conclusion}

Based on the hadiths related to 1-10 integers and integer operations that have been described. Then the hadiths are assembled with 1-10 integers and integer operations include HR. Bukhari 40; 71; 15; 33; 1334; 1761; 1109, HR Muslim 19; 1984; 1513; 1991, HR. Darmini 3174, HR. Ibnu Khuzaimah 301, and HR. Tirmidhi 565. 


\section{Bibliography}

Abdussakir, \& Rosimanidar. (2017). Model integrasi matematika dan al-quran serta praktik pembelajarannya. Seminar Nasional Integrasi Matematika Di Dalam Al-Quran (pp. 1-16).

Altman, H. (2019). Integer complexity: the integer defect. Moscow Journal of Combinatorics and Number Theory, 8(3), 193-217. https://doi.org/10.2140/moscow.2019.8.193

Asyhari, A. (2017). Literasi sains berbasis nilai-nilai islam dan budaya Indonesia. Jurnal Ilmiah Pendidikan Fisika Al-Biruni, 6(1), 137-148. https://doi.org/10.24042/jpifalbiruni.v6i1.1584

Baba, M. A. (2018). Dasar-Dasar dan ruang lingkup pendidikan islam di Indonesia. Jurnal Ilmiah Iqra', 6(1), 1-18. https:/ / doi.org/10.30984/jii.v6i1.616

Buijsman, S. (2019). Learning the natural numbers as a child. Nous, 53(1), 3-22. https://doi.org/10.1111/nous.12219

Davarpanah, A., \& Mirshekari, B. (2019). Mathematical modeling of injectivity damage with oil droplets in the waste produced water re-injection of the linear flow. European Physical Journal Plus, 134(4), 180. https:/ / doi.org/10.1140/epjp/i2019-12546-9

Direktorat Jendral Pendidikan Islam, K. (2011). Kementerian Agama RI. Program, (3), 46.

Dudley, U., \& Dudley, U. (2012). The number of divisors of an integer. In A Guide to Elementary Number Theory (pp. 29-30).

https:/ / doi.org/10.5948/upo9780883859186.010

Hapiz, A., Affifudin, M., Annisa, H., Rofiki, I., \& Abdussakir, A. (2019). Bilangan pecahan dalam al-Qur'an dan hadits, 5(1), 72-80.

Mutijah. (2018). Model integrasi matematika dengan nilai- nilai islam dan kearifan lokal budaya dalam pembelajaran matematika. Jurnal Pendidikan Matematika, 1(2), 52-75.

Nasution, A. A. (2014). Konsep dasar pendidikan islam. Jurnal Thariqah Ilmiah Vol. 01, No. 01 Januari 2014, 1(1), 3-15.

Nihayati. (2017). Integrasi nilai-nilai islam dengan materi himpunan (kajian terhadap ayat-ayat al- qur'an). Jurnal Edumath, 3(1), 65-77. Retrieved from https:/ / ejournal.stkipmpringsewulpg.ac.id/index.php/edumath/article/download/285/175

Nu'man, M. (2016). Pembelajaran matematika dalam perspektif al-Quran. JPM : Jurnal Pendidikan Matematika, 2(1), 39-49. https://doi.org/10.33474/jpm.v2i1.205 
Suwarto, S. (2018). Konsep operasi bilangan pecahan melalui garis bilangan. Mosharafa: Jurnal Pendidikan Matematika, 7(3), 327-336.

https://doi.org/10.31980/mosharafa.v7i3.73

Tristianto, D., Linawati, L., \& Susanto, B. (2018). Penerapan bilangan kompleks untuk menyelesaikan soal-soal geometri datar. d'CARTESIAN, 7(1), 8-14. https://doi.org/10.35799/dc.7.1.2018.19548

Wulandari, S., Hendrawati, N. E., Adawia, A., Dinantika, T., Rofiki, I., \& Abdussakir. (2019). Learning integrative mathematics on the set material in the al-Qur' an study. In Proceeding International Conference on Islamic Education (ICIED) (Vol. 4, No. 1, pp. 259-265).

Yuniati, S., \& Sari, A. (2018). Pengembangan modul matematika terintegrasi nilai-nilai keislaman melalui pendekatan Realistic Mathematics Education (RME) di Provinsi Riau. Jurnal Analisa, 4(1), 157-165. https:/ / doi.org/10.15575/ja.v4i1.1588

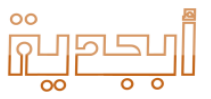

